\title{
A timeline for the urbanization of wild birds: the case of the lesser kestrel Falco naumanni
}

\author{
${ }^{1}$ Negro, JJ, ${ }^{2}$ Prenda, J, ${ }^{3}$ Ferrero, JJ, ${ }^{4}$ Rodríguez, A. \& ${ }^{5}$ Reig-Ferrer, A.
}

${ }^{1}$ Department of Evolutionary Ecology, Estación Biológica de Doñana (EBD-CSIC), Av. Américo

Vespucio 26, 41092 Seville, Spain. Email: negro@ebd.csic.es

${ }^{4}$ Grupo de Ornitología e Historia Natural de las Islas Canarias, GOHNIC, Canarias, Spain. Email: airamrguez@gmail.com

${ }^{5}$ Grupo de Investigación Zoología de Vertebrados. Universidad de Alicante. E-03080 Alicante, Spain. Email: areig@ua.es

Corresponding author: Juan J. Negro

\begin{abstract}
The Lesser kestrel (Falco naumanni) evolved as a separate species in the Old-World kestrel radiation starting in the late Miocene. Therefore, this urban colonial raptor has only become a major town dweller recently in its evolutionary history, and just in part of its breeding range (the Western Palearctic). Today, more than 95\% of lesser kestrel colonies in Spain and other Mediterranean countries are on buildings, and the few remaining are on rocky outcrops, that may have been the original nesting substrate for this cavity-nesting bird. Lesser kestrel fossils are well represented in cave sites, and their paleontological distribution, spanning to form the Early Paleolithic to the Epipaleolithic, agrees well with its current breeding distribution. According to classical sources, such as the works of Columella and Pliny the Elder, and the presence of a skeletal remain in a Roman villa near Madrid, lesser kestrels may have nested in buildings and in urban settings for at least 2000-2500 years. However, there are no surviving colonies in structures older than 1400 years in Andalusia, nor in Spain. For a sample of 349 colonies on ancient buildings, a majority of the structures had been erected in the $15^{\text {th }}$ and $16^{\text {th }}$ centuries, this putting a time limit of $400-500$ years to the existence of those seemingly immemorial colonies. For specific towns and buildings, written references for the presence of lesser kestrel colonies do not go back more than 200 years. In fact, the Cathedral of Sevilla may be the structure with the longest continuous occupation by lesser kestrels recorded up to present time, from at least Cook's (1934) notes to the 2020 breeding season. Lesser kestrels were possibly too common in human settlements in the past as to be noted as special. This may explain the scarcity of references to the species until the 19th century. In any case, the same lack of concretion affects the other major Eurasian urban birds, as no timeline exist for the urbanization process of any other bird species. We propose that lesser kestrels became urban breeders when both adequate cavities and cereal agriculture were developed in their breeding range, several millennia ago. However, specific urban colonies, contrasting with the stability of geological substrates, have adaptively moved from building to building when older ones become ruinous or were rebuilt, and new options became available throughout History.
\end{abstract}


Keywords: urban wildlife, Falconidae, cavity nester, coloniality, human habitat

\section{Introduction}

The cohabitation of animal species with humans in urban environments has only been possible since the inception of permanent settlements in the Holocene, less than 12,000 years BP. Nonetheless, some urban species may have a much longer and previous association to human dwellings along the Pleistocene, as cave species shared breeding, roosting or even foraging habitat with cave people (Larson et al. 2004). One well documented case is the rock dove Columba livia (Blasco et al. 2014). This species is the most cosmopolitan urban bird species nowadays (Aronson et al. 2014), present in practically every human village or town in the World. Rock doves were already breeding in caves in prehistory, where they were consumed by Neanderthal peoples and, after their extinction, by modern humans in the same locations (Blasco et al. 2014).

The relationship between cave people and the set of cave-dwelling bird species was generally one of predation for consumption, but some species were also coveted for the ornamental value of their feathers (Peresani et al., 2011, Finlayson et al. 2012). Raptors figured prominently among these species with a symbolic value, including large species such as bearded vultures Gypaetus barbatus, but also the small kestrels, as with the red-footed falcon Falco vespertinus (Peresani et al. 2011).

The process of urbanization for certain bird species that have established urban populations in cities in recent years have been relatively well documented (see Chace and Walsh 2006 for a review). In the New World, where humans arrived late -about 18,000-30,000 years ago (Ardelean et al. 2020)-, corporate architecture and urban settlement did not start until about 4.000 years before present at Caral, in Peru (Shady Solis et al. 2001). Rather late compared to 10.000 years BP estimated for cities like Jericho in the Old World. However, North America was mostly devoid of permanent cities until the arrival of Europeans, and the oldest continuously occupied city in the United States, St. Augustine, was founded by Spaniards in 1565 (Ring et al. 2013). In North America, genuine urban birds, considering as such those nesting normally on buildings (Erz 1966), all have a post-colonization European origin, and were thus transported: house sparrows were first released in Brooklin, NY, in 1851 (Moulton et al. 2009); the starling was introduced in Central Park, NY, in 1890 (Thacher Cooke 1928), and the rock dove was introduced in the early 1700's (Schorger 1952). The peregrine falcon, with a large urban population in North American cities today, was in fact introduced in urban environments in the second half of the $20^{\text {th }}$ century (Gahbauer et al. 2015).

Species breeding on buildings are few, they tend to be colonial, all have the ability of "cliff-breeding" (Erz 1966, Larson et al. 2004), and include, apart from the cosmopolitan-viaintroductions house sparrows, starlings and rock doves (Aronson et al. 2014), the white stork Ciconia ciconia and the lesser kestrel Falco naumanni in Mediterranean countries. Other synanthropic avian species that may have an ancient association with human buildings are the jackdaw Corvus monedula, house martin Delichon urbicum, the barn swallow Hirundo rustica, and different swift species (Apus spp.). Some owls may also be found in buildings, including the 
little owl Athene noctua, and the barn owl Tyto alba. The latter has become the quintessential farmland bird around the world, although, quite paradoxically, recent population declines have been attributed to increased urbanization (Hindmarch et al. 2017).

However, for the seemingly ancient urban bird colonizers of European cities mentioned above, little is known of how and when they became urban birds. Historical accounts before the $19^{\text {th }}$ century are scarce. Remains in archeological sites of the classical period (i.e., Roman and later) include very few bird specimens (García Petit 2017). The few attempts to model the urbanization process of bird species have resulted very simplistic: current paradigm is that hole nesting species became urban as soon as they found cavities in buildings and there was food for them in the city itself or in the surroundings (e.g., SummersSmith 1988, pp 281-282, for the house sparrow). But it is unknown whether urban colonies stayed continuously in any given location or suffered extinctions and recolonizations (Levins 1970), as would be expected of metapopulations (Keymer et al. 2000, Serrano and Tella 2003).

The picture is indeed complex, as all species involved have kept out-of-the-city populations with which there has been genetic admixture (e.g., Alcaide et al. 2009 for lesser kestrels), so that no clear morphological adaptations (McDonnell and Hahs 2015) setting apart urban and rural breeding populations have yet been detected (but see Mueller et al. 2018 and Mueller et al. 2020 for genetic signatures of urbanization, or Watson et al. 2017, for physiological responses). Even though urbanization is an ever-growing process, and although some urban breeders keep the largest avian populations worldwide (house sparrows, starlings and rock doves number hundreds of millions of individuals each, Aronson et al. 2014), others have declined sharply in the 20th century (e.g., white stork and lesser kestrel), with one urban breeder, the Bald Ibis Geronticus eremita, getting fully extinct in Europe and on the verge of extinction globally (Del Hoyo et al. 1992). Recently, it has been suggested that cities may become ecological traps for birds, as their breeding success is often lower than in rural areas (Pollock et al. 2017). Assessing whether some species have bred for centuries or even millennia in urban environments may thus shed light on particular adaptations for long-term cohabitation with humans (see, e.g., Erz, 1966, McDonnell and Hahs 2015, Møller and Xia 2020).

The lesser kestrel Falco naumanni is a colonial small falcon, with fully or partially migratory populations in Eurasia (Negro et al. 1991). About 95\% of breeding couples in the Iberian peninsula (Iberia onwards), the largest European population (González and Merino 1990), nest on buildings, and a majority of them do so inside towns or cities. Lesser kestrels are also urban in all countries in the western end of its distribution, currently having major breeding populations in Spain, Italy, Greece, Turkey, and Morocco (Negro 1997). This makes the lesser kestrel the most urban of all birds of prey in the Western Palearctic, and possibly in the world. Notwithstanding the current dependence of the species on human dwellings, we do not know when or how the urban habit emerged for this species. In fact, eastern populations in the Asian steppes and northern China have never been attached to human buildings, and have used (Brehm 1858) and still use rocky outcrops and sandy river banks instead (Parr et al. 2000).

We have used different data types, including paleontological records, ancient accounts and scientific literature from the $19^{\text {th }}$, as well as contemporary colony site data, to build a 
plausible scenario of how and when lesser kestrels became major urban breeders in the western portion of its distribution range. Our aim has been to elaborate a historical timeline for the urbanization process of the lesser kestrel, taking Andalusia, a stronghold for the species in Iberia with an intensively monitored population, as the main study area for our analysis.

\section{Material and Methods}

\section{Study species: the lesser kestrel}

The kestrels (17 species within the genus Falco) commenced to radiate in the late Miocene, within the last 8 million years, coincidental with the expansion of open habitats (Fuchs et al. 2015). Lesser kestrels are the sister taxon of 9 other extant kestrels. All together, these 10 species conform the Old World kestrel group, that evolved from a common ancestor about 4 million years ago (Fuchs et al. 2015). In fact, fossil data agree well with DNA sequence inferences: a large kestrel extinct species, Falco hezhengensis, that just predated the above mentioned radiation, has been found in the Late Miocene (about 6-7 Ma) Linxia deposits in China (Li et al. 2014).

The breeding distribution of the lesser kestrel spans from Iberia and Morocco in the Western Palearctic, to Mongolia and China to the east, always within the temperate belt of Eurasia and northern Africa around the Mediterranean Sea (Negro 1997). Therefore, lesser kestrel distribution overlaps very precisely with that of the ancient civilizations building the first cities (first in the Fertile Crescent, and later in the Middle East and around the Mediterranean at the apex of the Roman Empire in 117 AD) (Kumar 2019). The current wintering areas of the lesser kestrel are in sub-Saharan Africa, from Senegal to Chad for European populations (Rodríguez et al. 2009, Sará et al. 2019), and in Kenya and Tanzania, down to South Africa for Asian populations (Wink et al. 2004, Rodríguez et al. 2011). Lesser kestrels do not build a nest but lay their eggs on a ledge or hole. They breed both on natural substrates, including rocky outcrops and cave crevices, and on buildings in rural settings or within urban areas (Negro 1997). The urban habit is typical of the Western Palearctic portion of the breeding distribution, where more than $95 \%$ of nest sites are in buildings, either in towns or scattered in isolated constructions in the countryside. Eastern populations in the Asian steppes, however, often nest on rocky outcrops, or even the ground among stone accumulations (Parr et al. 2000). The human populations of the steppes were, and some still are, highly nomadic, and permanent settlements are few, well apart and with no or few large historic buildings.

\section{Data sources}

To assess the pre-urban distribution range of the species across time we have used the available fossil record for the species. A catalogue of circa 1.400 sites with Pleistocene avifaunas for the Palearctic was compiled by Tyrberg (1998), with an online supplement (Tyrberg 2008). Additional data were reviewed by Sánchez-Marco (2004). To assess the potential early urban breeding of lesser kestrels in the earliest Iberian cities, we have searched historiographic sources and archeological records. We have searched historiographic sources 
on the dating of ancient human settlements in Iberia. This region has been continuously inhabited since prehistory, with a transition from the Mesolithic to the Neolithic dated about 7.000-6.500 years BP (Alday-Ruiz 2009). The first written sources date from Roman times and have been preserved in much later editions (e.g., Columella (1471) and Pliny the Elderly (Plinius 1469). We have searched these sources for descriptions of kestrel species nesting on buildings.

For the different cultural periods after the Romans and before the 19th century, we have researched both building typologies compatible with the presence of lesser kestrel colonies (i.e., constructions with a potential abundance of cavities) and descriptions of bird species and its habits in natural history and falconry works. The lesser kestrel was given species status separate from the Eurasian kestrel by Fleischer in 1818. We have compiled references to the species in Iberia by resident naturalists and foreign travelers all along the 19th century.

The first population estimate ever for the species in Spain was given at the ICBP Conference held in 1975 (Garzón 1977), and almost concurrently 14 selected colonies were surveyed by Franco and Andrada (1976) in southwestern Spain. However, the very first nationwide survey was not conducted until 1989 (González and Merino, 1990). Since then, other population estimates have been made in different regions and provinces. One of us (JJN) has monitored lesser kestrels in Andalusia, southern Spain, since 1989 to 2020. Considering that Franco and Andrada's colonies were mainly in Andalusia and were also part of our survey, we have data for a period of 46 years in selected colonies, this making the only long-term study on colony occupancy available for the species so far. The Autonomous Government of Andalusia monitors the population totally or partially (i.e., a subsample of colonies) every two years since 2003. We have had access to all their data and have used them for some of our analyses. For Extremadura, bordering Andalusia to the northwest and also having a large lesser kestrel population (González and Merino 1990), we also have had access to the monitoring data collected under the coordination of the Autonomous Government.

\section{Data Analyses}

Using the available databases for lesser kestrel colonies in both Andalusia and Extremadura, we have used construction dates for historic structures $(n=349)$ located on defensive walls, towers, castles, palaces and religious buildings (mainly churches but also chapels, convents and monasteries), and have determined the oldest possible continuous occupation by the kestrels in those structures. We obtained construction dates from different sources including provincial catalogues of historic monuments and municipal archives. In some cases, exact dates are unknown and only an approximate date is given (e.g., 12th century). In case construction works took decades to complete, as with some cathedrals, we used the later date provided.

To estimate colony turnover at urban colonies (i.e., colony-desertion rates), we used data for the colonies within our own 46- and 30-years long monitoring schemes.

Recolonization of some colonies previously deserted has also been observed and the dates are given.

\section{Distance to cliffs}

The vast majority of the lesser kestrel colonies $(97.5 \%, n=1285)$ in the databases we used are located, or were located if they were deserted during the monitoring period, in human-made structures in cities, towns or in buildings scattered in the countryside. In 
addition, colony locations were overwhelmingly surrounded by open agricultural land with a predominance of cereal crops and sunflower, which was introduced in Spain as a major culture for oil production in the second half of the 20th century (Negro 1991). Natural substrates where kestrels may establish colonies are rocky outcrops. In Andalusia these are available on the mountain areas on both sides of the Guadalquivir valley, the major river in Andalusia. In fact, a majority of the Andalusian colonies are located within the valley at varying distances from natural cliffs. We have estimated the minimum distance from all colonies to natural cliffs on the borders of the valley to compare it to distances travelled by lesser kestrels during the breeding season (data are available from previous studies), and therefore to infer whether lesser kestrels would be able to exploit the large herbaceous cultures of the Guadalquivir river should have they kept the original habit of nesting on rocky outcrops.

To assess spatial distribution of nesting colonies in relation to cliff availability, we used the complete database of breeding colonies of the Autonomous Region of Andalusia ( $n=1,285$ nesting colonies) and a $100 \mathrm{~m}$-resolution a slope raster layer available at the Environmental Information Network of Andalusia (REDIAM;

http://www.juntadeandalucia.es/medioambiente/site/rediam). For each colony, we calculated the distances to the nearest cliffs, i.e. pixels with a slope angle equal or higher than 50. Analyses were conducted in Qgis version 3.8.2 (Open Source Geospatial Foundation Project, http://qgis.osgeo.org).

\section{Results}

\section{Fossil record}

The lesser kestrel is a relatively well represented species in paleontological sites ( $n=32$ different sites, including 31 caves and one open site, 47 specimens), with numerous records all across the Mediterranean and to the East, up to the Altai Mountains in Mongolia (Fig. 1). Iberia and adjacent Balearic islands is the region with a majority of both individual sites (20 sites out of 32 in our sample) and specimens $(65.9 \%, n=47$ specimens, distributed from the early Paleolithic (about 1 million years BP) to the Epipaleolithic (10,000 years BP), suggesting the Lesser kestrel may have been present in at least parts of the region all along the Pleistocene, perhaps taking advantage of the refuge characteristics of Iberia during glacial times. The two oldest fossils, from the early Paleolithic, were both excavated in Iberia. 


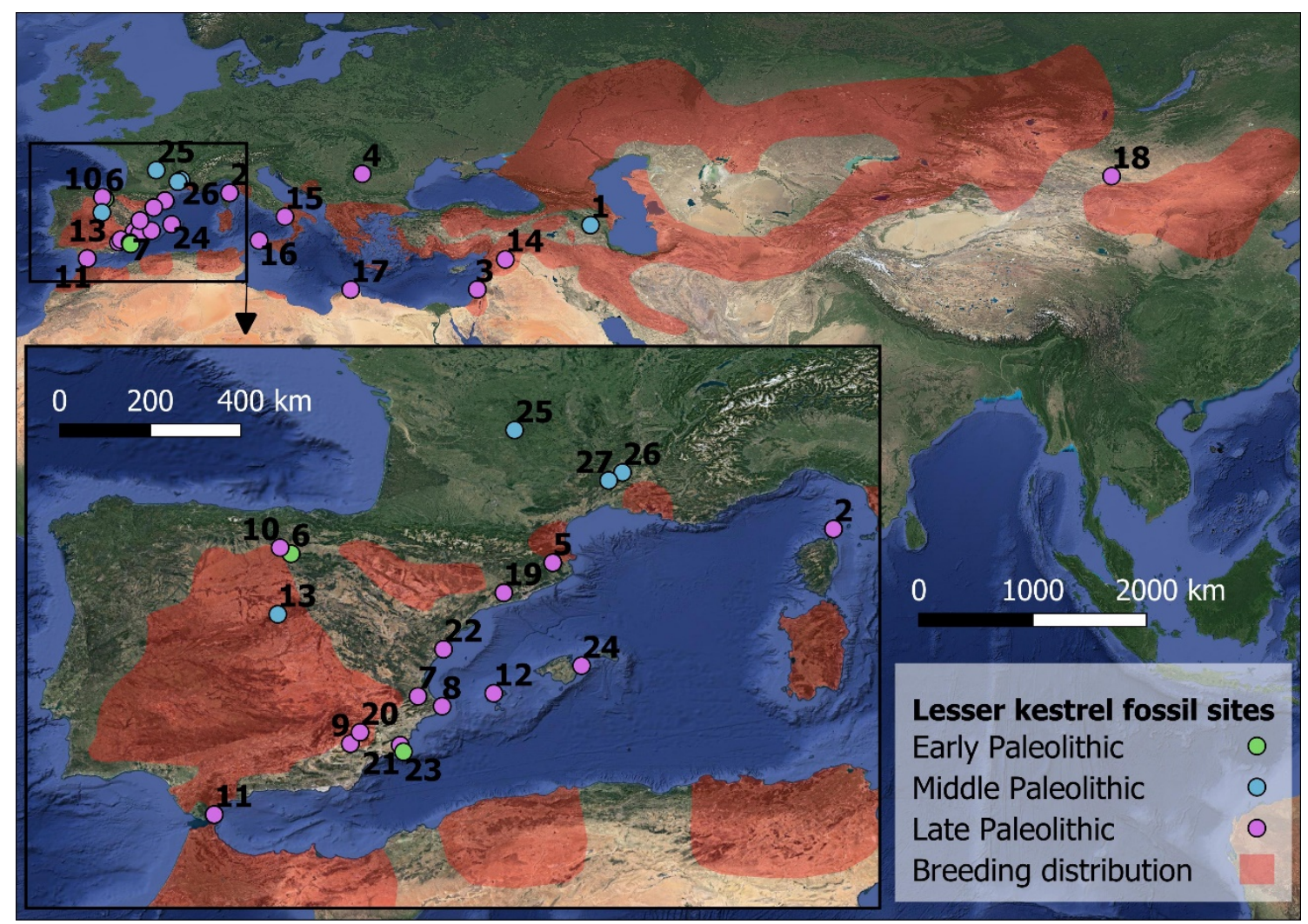

Fig. 1. Location of fossil remains of lesser kestrel with indication of the date of the layer where they were found. The current breeding distribution of the species is shown as an ochre shade. Each number denotes a site (1. Azykh, Nagorno Karabakh. 2. Grotte de la Coscia, Corsica. 3. Hayonim Cave, Galilee. 4. Pestera Cioarei, Gorj. 5. Arbreda, Girona. 6. Atapuerca, Burgos. 7. Cova Negra, Xátiva. 8. Cova de les Cendres, Alicante. 9. Cueva de Ambrosio, Almería. 10. Cueva de Valdegoba, Burgos. 11. Gibraltar (5 different caves). 12. Cova des Pouas, Ibiza. 13. Pinilla del Valle, Madrid. 14. Tell Mureybat, Raqqa. 15. Castelcivita, Salerno. 16. Grotta delle Pecore. Trepani. 17. Haua Fteah. Cyrenaica. 18. Tsagan Agui, Gobian Altai. 19. Cova de la Guineu, Guardiola de Fonrubí. 20. Cueva Negra, Murcia. 21. Sima de la Palomas, Murcia. 22. Cau D'en Borrás, Castellón. 23. Cueva Victoria, Murcia. 24. Cova Nova, Capdepera. 25. La Fage, Corréze. 26. Orgnac, d'Orgnac-l'Aven. 27. Salpêtre de Pompignan, Gard.

\section{Major architectural landmarks through history in Iberia}

\section{Pre-Roman period}

The first cities Iberia with stone buildings and surrounded by defensive stone walls, a potential substrate for cavity-nesting birds, were built about 5,000 years BP (e.g., Los Millares, Aranda-Jiménez 2020). In a later period, just prior to the Roman conquest, cities like Pintia of the Vaccean culture in northern Iberia were protected by $4 \mathrm{~m}$ high stone walls which were more than $1 \mathrm{~km}$ long and were reinforced with numerous turrets (Sanz et al. 2010). Many other walled cities called oppida (i.e., hill fortresses) dotted the landscape (Sanz et al. 2011). However, ancient Iberian cities were destroyed, built over or buried after Roman occupation (starting 2200 years BP), and only some foundations or scattered pieces of walls remain today. 
No lesser kestrel colonies are currently located in any of the ruins of Iberian settlements, and no kestrel remains have been reported from excavation sites. Although conditions may have been suitable in the past, we lack evidence that kestrels ever bred on ancient Iberian settlements.

\section{Roman Hispania}

Romans built cities and villas extensively in Iberia across 7 centuries (from $200 \mathrm{yr} \mathrm{BP}$ to the 5th century). The human population ranged from 4-6 million in this period (McEvedy and Jones 1978). No less than 186 medium to large cities were founded in Hispania, linked by $40,000 \mathrm{kms}$ of roman roads. Apart from large public buildings such as theaters and temples within major cities, the romans erected colossal infrastructures including aqueducts and stone bridges. Many cities were also surrounded by defensive stone walls, such as the ones encircling the city of Lugo, in northern Spain, that built in the $2^{\text {nd }}$ century are still standing and well preserved. They are $2130 \mathrm{~m}$ long, reinforced by 85 turrets (Richmond 1931). All these large constructions made of stone, bricks and/or concrete may have provided adequate nesting sites for hole nesting birds, including the lesser kestrel, since the time they were erected. The skeletal remains of a lesser kestrel were unearthed from a roman villa at Tinto Juan de la Cruz (Madrid Province, central Spain), dated in the $1^{\text {st }}-5^{\text {th }}$ centuries (García Petit 2017). Although numerous Roman monuments are still standing to some extent, no kestrel colonies are located on Iberian Roman ruins nowadays.

\section{Germanic invasions}

Following Roman domination, Iberia was ruled by the Visigoths and other Germanic peoples who come from central Europe, from the Vth to the 8th century (Collins 2004). Major architectural remnants from this period are stone churches and chapels that may have hold cavity nesting birds on their outer walls and towers. However, as with the preceding periods, no lesser kestrel colonies are currently located in these ancient buildings, all of which have suffered deep alterations through the centuries. Surviving ones have been in fact re-erected practically from scratch with modern restoration techniques in the 20th and 21st centuries (see supplementary material).

\section{Islamic ruling of Al-Andalus}

The next major architectural period was brought over by the Islamic peoples who entered Iberia from North Africa starting in the early 8th century (Kennedy 1996). They swiftly established themselves in practically the whole of the peninsula. The muslims built their castles, palaces and mosques on the foundations of the towns and villages previously erected by romans and goths, very often recycling building materials (such as the Alcazaba in Mérida, supplemental material). Muslims defended their settlements erecting either stone walls or using a particular construction technique locally called tapial (i.e., rammed earth), which left many regularly spaced holes called agujales (Fig Xsup). Having been erected closer in time to present day, many Islamic city walls and castles are still standing, particularly in Andalusia (southern Spain), where the muslims ruled the Kingdom of Granada until the end of the 15th century (Kennedy 1996). Extant lesser kestrel colonies abound in monuments of the peninsular Islamic period, mainly including castles and defensive walls, the oldest ones built in the 8th century (see fig. 5). We may thus infer potential continuous occupation of buildings by lesser kestrels in the portion of territory ruled by the muslims in Iberia, going back in time up to 1200 years.

\section{From the Renaissance to today}


Christians regained full control of Iberia in 1492 when they conquered Granada. However, they had started to control large areas from north to south in the preceding 3-4 centuries (O'Callaghan 2013). The Christians built numerous castles in their advance, as well as churches, monasteries and cathedrals, often enlarging or modifying the mosques and minarets previously erected by their predecessors, as with the cathedral of Sevilla, still holding a lesser kestrel colony known from at least the mid $19^{\text {th }}$ century (see below). This large building complex may have been continuously occupied by lesser kestrels for several centuries, since a mosque was first erected in the 12th century (https://whc.unesco.org/en/list/383).

In Fig. 5 we provide the number of lesser colonies in historical buildings in Andalusia and Extremadura on a century-by-century basis. Since the Renaissance, large public buildings used to be provided with numerous square holes on the walls for securing wooden scaffolding during construction, painting or repair works. These regularly spaces holes are called mechinales (see fig. 2Sup), and lesser kestrels finds in them optimal nesting places (Negro and Hiraldo 1993). A majority of kestrel colonies are located today in monuments built in the 16th18th centuries (Fig. 5), this reflecting the fact that a majority of the largest buildings with suitable nest-sites were erected in those centuries when the Spanish Empire was at its peak in extension and richness.

Lesser kestrels have also established breeding colonies in entirely new buildings erected in the 20th century, both within towns and villages, or in isolated and uninhabited rural constructions (González and Merino 1990). Nest-sites are generally under tiled or undulated roofs, although breeding pairs may use other holes or crevices. In Spain and other Mediterranean countries (e.g., Bux et al. 2008), lesser kestrels have been attracted to modern buildings by placing nest-boxes. Structures similar to dovecotes have been built for kestrels, called 'primillares', and some have been adopted by the species, particularly if juveniles were released in situ following the hacking method (Rodríguez et al. 2013).

\section{Foraging habitat requirements}

As explained above, nesting habitat in urban environments is a critical aspect for survival in a vulnerable small raptor like the lesser kestrel. But lesser kestrels also heavily depend on open lands for their diet mainly composed of orthopterans (Andrada and Franco 1976, Rodríguez and Bustamante 2008). In fact, a trade-off between productivity and survival in rural versus urban colonies, even if both types were on human constructions, was already noted by Tella et al. (1996). Rural colonies in isolated buildings may reach higher productivities of nestlings as foraging trips are much shorter, but may also suffer catastrophic predation of both young and adult birds from Martes foina and other predators. Urban colonies may have lower productivity due to longer distances to foraging grounds outside town, but are safer for the birds as they typically lack predators, which are excluded by human presence (Tella et al. 1996, Negro 1997).

The building of the first cities in the Neolithic was accompanied by the clearing of land for cereal agriculture (e.g., Summers-Smith 1988). In Iberia, roman domination implied the ploughing of extensive areas around towns and villas that were possibly as important for the lesser kestrels as the buildings themselves. Major agricultural regions already in Roman times have consistently been cultivated for two millennia until today using essentially two main crops -i.e., cereals and olive trees- in the case of Andalusia, that we use here as an example. Prior to the advent of agriculture, the areas where lesser kestrel thrive today are far from 
natural rocky outcrops, which are located in the mountain ranges bordering the large Guadalquivir river valley and other smaller river basins (Fig. 2). Andalusia achieved its current geological conformation before the onset of the Quaternary, although the sedimentary areas that conform the Guadalquivir river valley, where the bulk of the lesser kestrel colonies are today, were submerged under the sea until 5.5 million years ago.

The median of the distance to the nearest natural cliff for all colonies in the region is $13 \mathrm{~km}$, with some colonies located more than $40 \mathrm{~km}$ away from a natural outcrop (Fig. 3). The mean distance from the nest to the foraging site by kestrels during the chick rearing period is 2-3 km (Vidal-Mateo et al. 2019, Cecere et al. 2020). Therefore, the location of a majority of the colonies and their nearest foraging grounds today would be out of reach for lesser kestrels had they kept the habit of breeding in rocky outcrops.

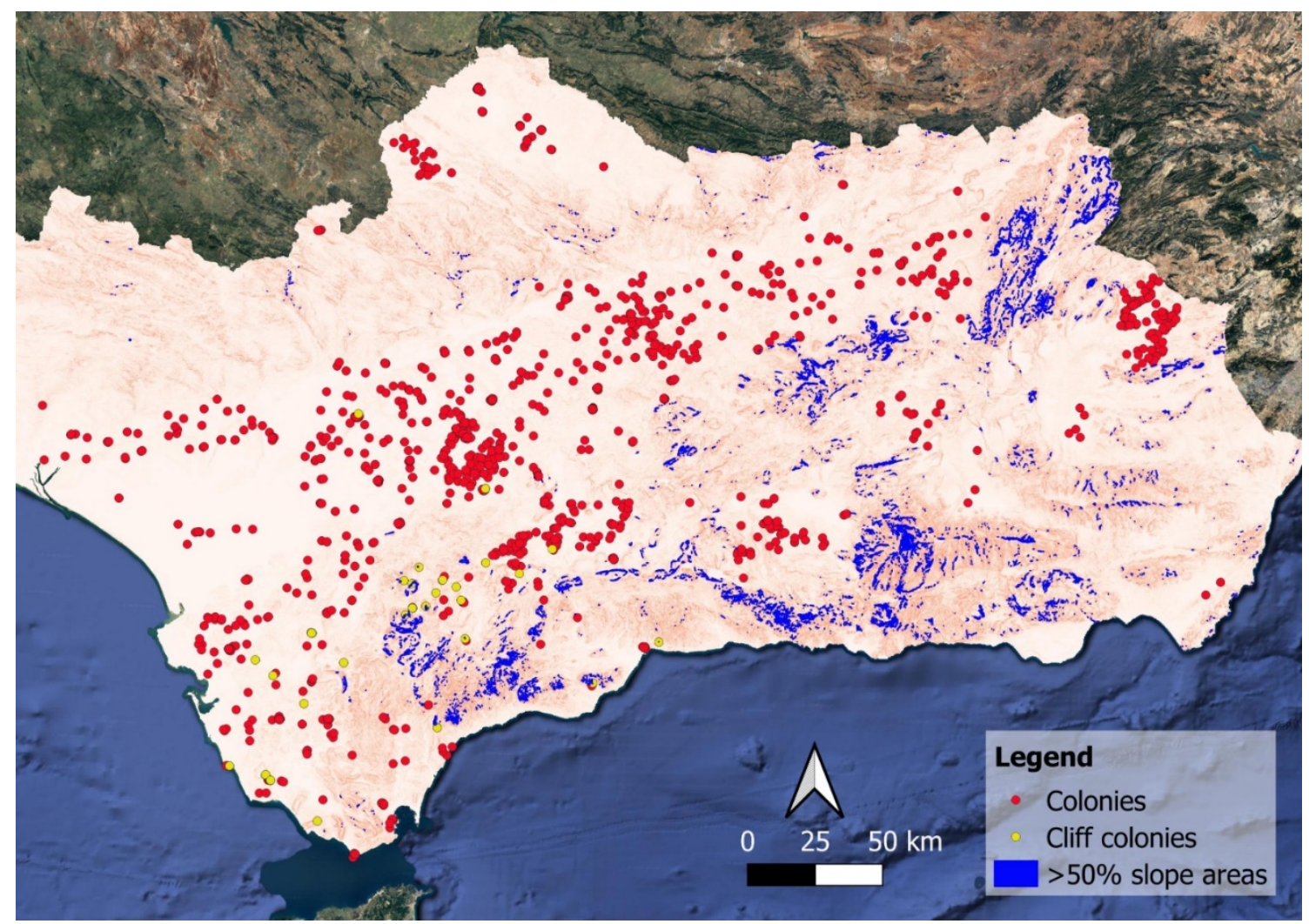

Fig. 2. Lesser kestrel colonies on a digital relief model of Andalucía (Southern Spain) in the 21st century (colonies monitored 2003-2019). Red dots: colonies on buildings ( $n=1252,97.5 \%)$. Yellow dots: colonies on rocky outcrops and coastal cliffs ( $n=33,2.5 \%)$. 


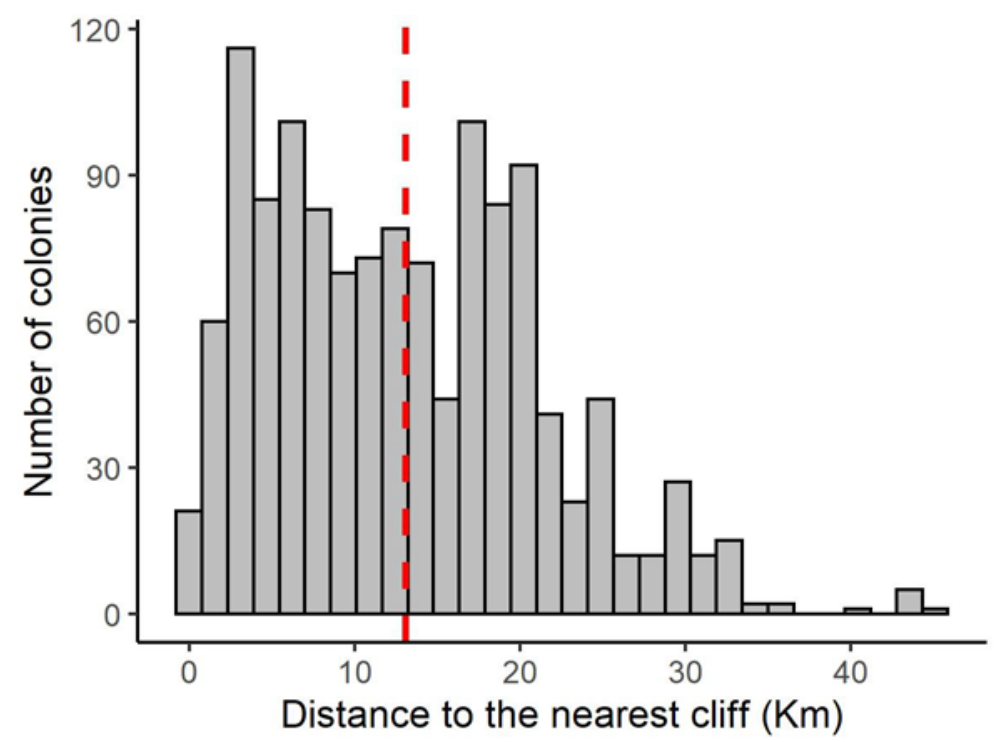

Fig 3. Distance to nearest cliff $(\mathrm{Km})$ of lesser kestrel colonies $(n=1285)$ monitored in 2003-2019 in Andalusia. The red broken line indicates the median distance $(13.5 \mathrm{~km})$, exceeded by $50 \%$ of the colonies.

\section{Urban kestrels in ancient written sources}

The first written references to kestrel breeding on human buildings are found in Columella (edition of 1471). Columella, who was born in the year 4 CE (Current Era) in Gades (currently the city of Cádiz in Andalusia), stated that kestrels are small raptors that almost always breed on the walls of buildings. Quoting Greek author Democritus, Columella also noted that kestrels may defend rock doves at dovecotes from the attack of larger raptors, and thus help pigeon breeders to preserve their animals. Lesser kestrels gather to mob both diurnal and nocturnal birds of prey when at the colonies, but to defend themselves and their progeny. Negro (1997) described how barn owls Tyto alba-known to kill adults in their nests occasionally- provoked immediate aggregation of adult kestrels (sometimes up to 25) if flying in daytime. Mobbing kestrels called loudly, diving on the intruder and pursuing it out of the colony (Negro 1997). Eurasian kestrels and jackdaws are also driven off when approaching nest sites (Bijlsma et al 1988). This communal defensive behavior is possibly the one first described by Democritus and later by Columella. Pliny the Elder, another Roman naturalist contemporary of Columella who travelled extensively in Hispania, also quotes the same Democritus' passage on kestrels and pigeons at dovecotes in Book $10^{\text {th }}$ (Chapter 52) in his Naturalis Historiae (Plinius, edition of 1469).

After the aforementioned classical authors there is a great void, and the next surviving reference to kestrels breeding in "tall buildings, temples, towers and walls" is given by Ulisse Aldrovandi, an Italian author of the 16th century, in his work "Ornithology, the History of Birds" (1599). Almost concurrently, the Portuguese Diogo Fernandez Ferrerira (1616) mentions in his falconry book the existence of two kestrel species, one breeding in towers-possibly the lesser kestrel- and the other one on trees -the Eurasian kestrel-. The Spaniard Gerónimo Huerta (1624) translated Pliny's Natural History of Animals adding comments and referring to the urban habit of some kestrels. A century later, the Italians Manetti et al. (1767-1776) included the first known color drawing of an adult male lesser kestrel that they called Gheppio di Torre (i.e., Tower Kestrel) in a clear reference to the habit of nesting in buildings. The references given in this and the following section have been incorporated into Fig. 4 to create a timeline for kestrel urbanization according to written sources. 


\section{References to urban breeding of lesser kestrels in the 19th century}

The interest for nature and zoology sharply increases in the 19th century with regard to preceding centuries (see Fig. 4). Several foreign and local naturalists attest to the presence of Lesser kestrels breeding in buildings in Spain, mainly in Andalusia, with quotations clearer than any time before, as specific places and dates are given in travelers' books or natural history works. Cook (1834), referring to Andalusia, stated that lesser kestrels "live in the cities, breeding in the lofty towers which have replaced the minarets of the Moors". Machado (1854), who was Dean of the University of Sevilla and established the first Natural History Museum in the city, noted that lesser kestrels nested in abandoned towers and buildings all across the province of Sevilla, where they were "very common". He undoubtedly referred to the lesser kestrels, and not to the Eurasian kestrel that is sedentary, as Machado correctly specified that urban kestrels arrived from migration in February and left in October. Alfred Brehm (1858), a German zoologist who toured Spain for a year, reported that lesser kestrels were "frequently observed as couples, families and groups in the cities of southern and central Spain, where, as in Athens (Greece), breed in buildings and church towers". He specifically refers to lesser kestrels breeding in belfries in Madrid, Sevilla and Granada. Lilford (1865) stated: "I think, in April and May, the lesser kestrel are the commonest birds in Andalusia, with perhaps the exception of the Bee-eater (Merops apiaster). Every church-steeple, belfry, and tower, every town and village, every ruin swarms with them". Saunders (1871) similarly reported that "the birds swarm about old buildings". Irby (1875) a British officer stationed in Gibraltar, noted that vast numbers of lesser kestrels nested on the Rock itself, chiefly on the north face. Also very abundant in rocks and ruins, particularly on the "old Moorish buildings and towers, of which there are so many in Andalusia". In some places, like the city of Sevilla, Irby wrote they "swarm like bees in a hive". The Spanish zoologist Arévalo Baca (1887) recorded lesser kestrels nesting at the Cathedrals of Sevilla and Jerez, where they still do as of 2020. He also mentioned colonies in the Cathedrals of Malaga and Granada, as well as in the Alhambra of Granada and the Alcazar of Segovia in central Spain.

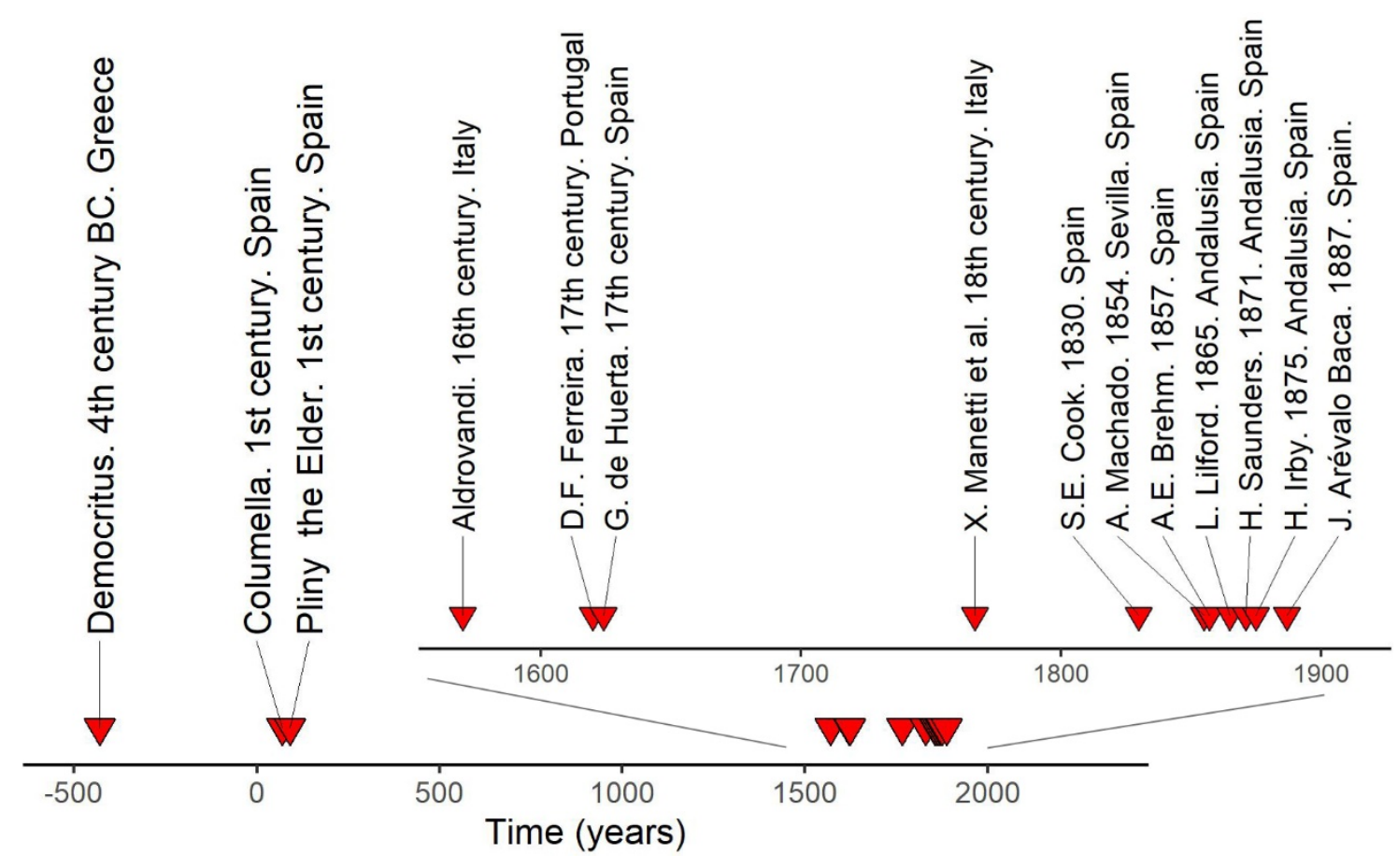


Fig. 4. Timeline showing written references to kestrels nesting in buildings. Prior to the 19th century, lesser and Eurasian kestrels were not considered different species, although some authors knew there were urban kestrels and wood kestrels.

\section{Longest potential continuous occupation of specific colony sites}

A majority of the structures holding kestrel colonies we were able to date $(n=349)$ were erected on the 15th and 16th centuries (Fig. 5). If we assume lesser kestrel established their colonies there right after construction, this give a maximum potential occupation time of 500-600 years for those modal structures (mainly religious buildings). The oldest structures of colonies tend to be defensive (i.e., Islamic walls, defensive towers in the countryside and castles). This may also be explained because few of these structures were newly built after the Christian Kings took full control of Iberia after conquering the Islamic Kingdom of Granada in 1492. It is also significant that $63 \%$ of structures with colonies were built during or before the 16 th century, and $90 \%$ before or during the 18th century. This would agree with the observations in the 19th century (see above), when reports always mentioned presence of kestrels in old buildings, towers and belfries.

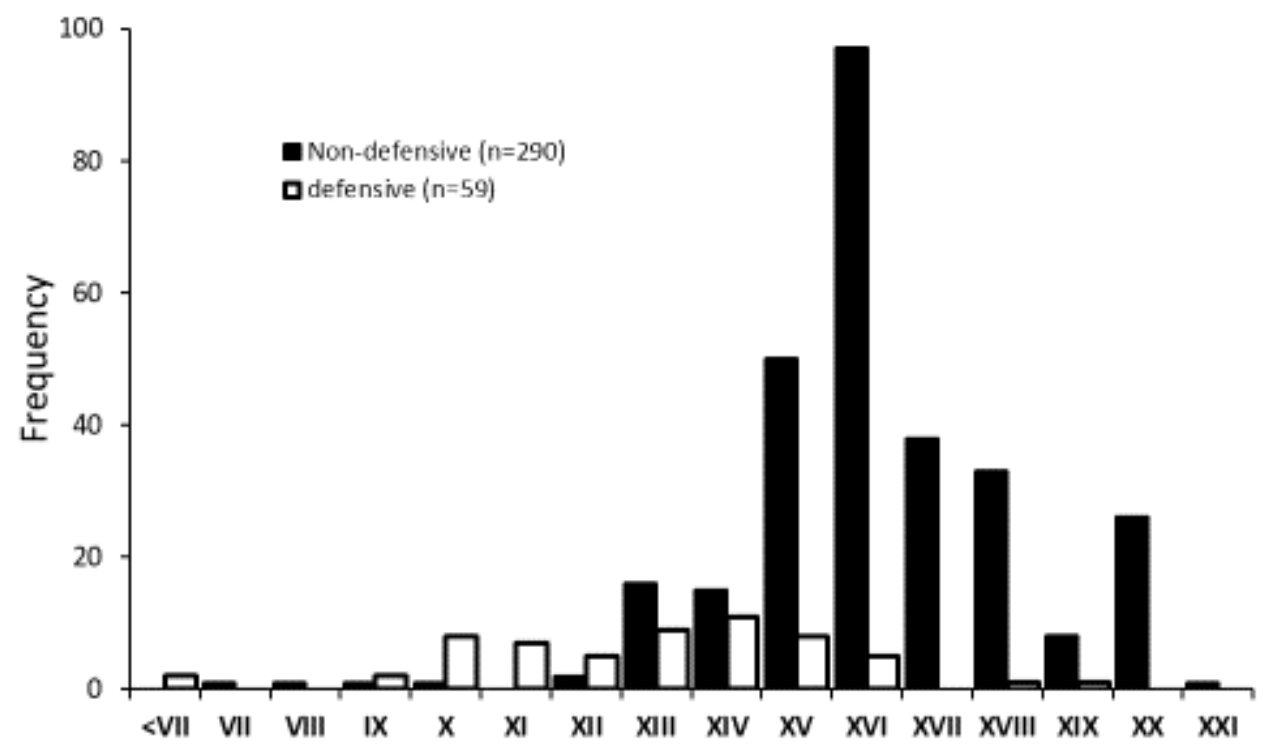

Fig. 5. Construction dates (by century until present) of human-made structures in towns or in the countryside holding lesser kestrel colonies at present (2003-2019). Black columns for nondefensive buildings (e.g., churches), white columns for defensive walls, towers and castles.

\section{Colony turnover}

We have been able to estimate colony turnover at specific buildings using two datasets. Franco and Andrada (1976) located 15 lesser kestrel colonies in Andalusia and Extremadura for a dietary study conducted in 1973. Fourteen of these colonies have been monitored intermittently until 2019 by JJN. Of these 14 colonies, 4 were deserted by kestrels for unknown reasons before 1989, although three of them were recolonized after 1995 (21\%). Four disappearing colonies represent a $28 \%$ desertion rate in 46 years. The second dataset comprises 25 colonies in as many different buildings in the province of Sevilla which started to be monitored in 1989 and up to 2019 . Ten (40\%) of these colonies have been deserted in the 
30 years monitoring period. As for the reasons for colony desertion, in some cases cavity loses due to restoration work was documented, but in other cases the reasons are unknown.

\section{Discussion}

The Lesser kestrels started to diverge from the remaining of the kestrel lineage between 2-4 million years ago, and we can consider this to be the time the lesser kestrel stands as a separate biological species. The lesser kestrel is a hole nesting species: as with the remaining members of the Falco genus (Ferguson-Lees and Christie, 2001), they do not build a nest of their own and directly lay the clutch on a crevice or hole (Negro 1997). Natural nest sites excluding buildings or other human-made structures are holes in caves, rocky outcrops, river banks and stone accumulations on the ground (Brehm 1895, Negro 1997, Parr et al. 2000). They only rarely nest on tree holes, or on tree nests built by other birds, as done by two other Eurasian small falcons, F. vespertinus, and the Amur Falcon, F. amurensis, that typically nest on unused corvid nests on trees (Ferguson-Lees and Christie, 2001).

Given that the first permanent settlements were built by humans at the onset of the Neolithic, about 10,000 years ago, lesser kestrels have been necessarily nesting on natural substrates other than buildings for more than $99.5 \%$ of their evolutionary time as a separate species. The oldest fossil of a lesser kestrel in Iberia, the one at Cave Victoria in Murcia (Tyrberg 2008), is about one million years old, this demonstrating, along with other more recent fossils in other peninsular sites, that lesser kestrels have been regular inhabitants of Iberia in the Pleistocene, and did not necessarily expand their distribution range with the advent of urbanization and agriculture in the Mediterranean.

In Iberia, the first permanent human cities that may have hold lesser kestrel colonies because they incorporated high stone walls and actual buildings -not huts- were erected about 5000 years ago. Again, lesser kestrels became urban breeders in Iberia very late in their lifetime as a breeding species in the region. Nowadays, less than $2.5 \%$ of lesser kestrel colonies in Andalusia are located in rocky outcrops, and thus in natural substrates, and a majority is on buildings, whether isolated in the countryside (mainly abandoned farm houses and old castles or ancient defensive towers), or within towns and cities (often on churches and other large such as palaces or convents, as well as remains of defensive walls, but also on inhabited private houses).

The first written record of kestrels nesting on buildings is that of Columella (edition of 1471), who was born and lived in southern Spain. He did not separate the lesser and the Eurasian kestrel, that may have lived in sympatry in the region. From the behavioral description in his work (i.e., colonial and urban nesting, as well as communal mobbers of larger raptors when nesting on dovecotes) we may infer he was referring to lesser kestrels. Roman built dovecotes similar to the traditional ones made of rammed earth still in use in northern Spain, with a well preserved representation in the Nile mosaic of Palestrina (Central Italy) composed in $100 \mathrm{BC}$ (Germanidou 2015). Lesser kestrels do use them nowadays for nesting (personal observations). Dovecotes are ideal colony structures for kestrels, as the size of the pigeon holes is adequate for them, and coexistence with the pigeons is neutral, as the lesser kestrels never prey on pigeon squabs, and do not disturb the adults (supplementary material). This behavior was essential for the kestrels to have been permitted as wild breeders by dovecote owners. In addition, dovecotes in Spain have been set in cereal-producing regions, again perfect foraging grounds for these insectivorous kestrels. 
We may set the move of lesser kestrels from natural sites to the cities in Roman times, about two millennia ago in Iberia. Earlier occupation of buildings may have been possible in earlier urban civilizations to the East, in Mesopotamia, Egypt, the Middle East and the Balcans. As we said above, Columella quotes Democritus, a Greek philosopher and naturalist of the 4$5^{\text {th }}$ century BCE (Before Current Era) when describing kestrels at dovecotes. And the Parthenon in Greece, built precisely when Democritus was born ( 2460 years BP) has lodged lesser kestrel colonies until at least the 19th century (Brehm 1958).

Extant lesser kestrel colonies in Andalusia are located in a variety of human-made structures erected in different epochs. However, there are no extant colonies in the ancient remnants of pre-roman times, Roman monuments, and there are very few in the surviving buildings of the goths until the 8th century. Even if we may assume lesser kestrels were already urban and bred on human constructions, it is not surprising the ruins of those times do no longer hold breeding colonies. A majority of them collapsed over the centuries and have been covered by sediment of refuse. The ruins shown to the public today have all been excavated and partly rebuilt.

The lesser kestrel colonies on older buildings in Andalusia -and Spain- are the ones on defensive walls and castles of the Islamic period, about 1000 years old. Contrary to constructions from preceding periods, the Islamic ones have been standing for centuries, with or without further repairs. Additionally, Islamic constructions were mainly of rammed earth and stone ashlars, with numerous regular holes called agujales, which are the ones used by kestrels as nesting sites. The agujales surely permitted the formation of large kestrel colonies, as the ones described by 19th century authors (see results above) in the Andalusian cities and towns. The walls of the city of Seville at the end of the 12th century, in the Almohade period, was $7 \mathrm{~km}$ long with 116 turrets, and remained almost intact until the 19th century. Such a structure may have potentially lodged hundreds if not thousands of lesser kestrel nest sites, as this colonial species tolerate neighboring couples of conspecifics about $1 \mathrm{~m}$ apart, this following the average distance between neighboring agujales in the walls (Negro and Hiraldo 1993, Negro 1997, supplementary material). The size of the lesser kestrel, the smallest Iberian falcon with a body mass of 110-150 $\mathrm{g}$ as an adult, makes possible to enter the smallest agujales, with a section of about $12 \times 12 \mathrm{~cm}$ and $50-80 \mathrm{~cm}$ long (Negro and Hiraldo 1993).

After the Islamic domination period, their basic urban network remained quite unaltered in Andalusia, although new public architecture was built, particularly churches, convents and palaces. Many of these buildings incorporated an innovation called mechinales. These mechinales (see supplementary material) were slightly larger than the agujales ( $14 \times 15$ cms, see Negro and Hiraldo 1992), but also optimal for a hole-nesting and colonial species such as the lesser kestrels, as any given building or tower used to have hundreds of regularly spaced mechinales.

Today, a majority of lesser kestrel colonies take advantage of the presence of mechinales in large historic buildings. In our sample of dated monuments, a majority of buildings with colonies was erected in the 15th and 16th centuries, this setting a maximum period of occupation for the colonies of 500-600 years. There were possibly kestrels breeding before in other locations in the same towns, but its date of construction indeed determines maximum continuous occupation in every single building. This also brings out the question of possible colony persistence at any given site.

The concept that some colonies of common birds have been in particular places since time immemorial (see, e.g., us of thre term by Nicholson 1929 for heronries in the UK) needs to be narrowed down, as human buildings suffer alterations over the years/centuries due to 
fires, earthquakes (such as Lisbon's tsunami in 1755, which severely affected many towns in western Andalusia), or they are just rebuilt by the owners. All these events may have made formerly used places unsuitable for kestrels for a number of years, or even permanently. For this reason, we have estimated colony turnover on specific buildings in recent times. Four out of 14 lesser kestrel colonies monitored from 1973 to 2019 in buildings in Extremadura and Andalusia disappeared at some point (28\%). In another sample of 25 colonies monitored in towns of Andalusia from 1989-2019, 10 (40\%) disappeared. These rates may have been different in the past, and it is also true that lesser kestrels have colonized even modern buildings. Kestrels may also re-colonize formerly occupied colonies that they had deserted at some point. We know of at least 3 colonies in old structures near the city of Sevilla that were used as colonies in the 1970's, become deserted in the 1980's and were re-occupied in the 1990 's. A fast range expansion and population increase of lesser kestrels was recorded in northern Spain, where the birds occupied isolated constructions that became unused in rural areas at the end of the $20^{\text {th }}$ century (Jovani et al. 2008). All the above suggest, that even if the lesser kestrel population has generally kept its general breeding range, specific colony sites may have changed widely in history, and may not be as stable as certain falcon eyries on natural rock cliffs that have been used for millennia, as some gyrfalcon $F$. rusticolus nest sites in Greenland, which were studied using stable isotopes on guano accumulations and are considered "ecological magnets" (Burnham et al. 2009).

According to witnesses' accounts (see references above), individual lesser kestrel colonies possibly numbered hundreds of couples, and maybe thousands, in large fully walled cities such as Sevilla up to the 19th century, or even the first half of the 20th century in certain Andalusian towns (see, e.g., the observation of hundreds of kestrels at Arcos de la Frontera in Cadiz province by Riddell 1945). Nowadays, the largest colony in Spain is the one at the castle of Mairena del Alcor (Sevilla province) with 92 couples in 2020 (Bustamante et al. 2020). The colony on the Islamic walls and castle of Niebla (Huelva province) reached 300 couples at the onset of the 21st century, although it has decreased sharply in recent years (JJN personal observations). But the largest urban colony today is in the Italian medieval town of Matera, with about 1000 breeding couples (Cecere et al. 2020). These numbers give an idea of how large urban lesser kestrel colonies may have been up to a recent past.

Nesting habitat suitability is by no means the only factor determining the distribution of kestrels in the landscape. Churches and castles with an abundance of holes were also erected in towns located in mountain areas of Andalusia and Extremadura, but they hold no kestrel colonies (personal observations). Our analysis of colony location with regard to natural rocky outcrops outlines the importance of adequate foraging grounds for the species, which in Spain and other Mediterranean countries in the Western portion of its distribution is very dependent on herbaceous cultures (Negro 1991, Negro 1997, Rodríguez and Bustamante 2008). Lesser kestrels became largely urban, and still are in 'agro-cities', where they found both suitable nest sites safe from a majority of their predators (Tella et al. 1996), but also because they were close to adequate open habitat during the breeding season. Agro-cities were largely developed during the Roman domination period in southern Iberia (encompassing both Andalusia and Extremadura), and the Roman city map has remained almost intact over successive periods until today. The fact that numerous colonies are also established on scattered buildings in the countryside indicates that within-town breeding is not the only human-dependent strategy of lesser kestrels, and that the availability of prey nearby is also an essential component in the choice of nesting substrates. In rural areas of Hispania, major landownership rested on the Roman "villa rustica" (= farmhouse), which led to the Islamic "alquería", and the modern "cortijo" or "hacienda" (Vidal Teruel at al. 2010). Recently abandoned cortijos (in the late $20^{\text {th }}$ and early $21^{\text {st }}$ centuries) hold numerous small lesser kestrel colonies in the countryside of both Andalusia and Extremadura today (Bustamante et al. 2020). 


\section{Literature cited}

Alcaide, M., Serrano, D., Tella, J.L., Negro, J.J. (2009) Strong philopatry derived from capturerecapture records does not lead to fine-scale genetic differentiation in lesser kestrels. Journal of Animal Ecology 2009, 78, 468-475.

Alday-Ruiz, A. (2009). Late Mesolithic and Early Neolithic in the Iberian peninsula: chronology and phases. Munibe 60, 157-173.

Aldrovandi, Ulisse (1599). Ornithologiae hoc est de avibus historiae libri XII. Bononiae. Apud Jo. Baptistam Bellagambam [in Latin].

Aranda-Jiménez, G., Díaz-Zorita Bonilla,M., Hamilton, D., Milesi, L., Sánchez Romero, M. (2020). The radiocarbon chronology and temporality of the megalithic cemetery of Los Millares (Almería, Spain). Archaeol. Anthropol. Sci. 12, 104.

Ardelean, C.F., Becerra-Valdivia, L., Pedersen, M.W. et al. (2020). Evidence of human occupation in Mexico around the Last Glacial Maximum.Nature584,87-92.

Arévalo Baca, J. (1887). Aves de España. Madrid: Imprenta de los Sres. Viuda é Hijo de Aguado.

Aronson MFJ, La Sorte FA, Nilon CH, et al. (2014). A global analysis of the impacts of urbanization on bird and plant diversity reveals key anthropogenic drivers. Proc $R$ Soc B Biol Sci 281:20133330.

Bijlsma, S., Hagemeijer, E.J.M., Verkley, G.J.M., Zollinger, R. 1988. Ecological aspects of the lesser kestrel Falco naumanni in Extremadura (Spain). Rapport 285. Werkgroep Dieroecologie. Katholieke Universiteit Nijmegen.

Blasco, R., Finlayson, C., Rosell, J. et al. (2014). The earliest pigeon fanciers.Sci Rep 4, 5971. https://doi.org/10.1038/srep05971.

Brehm, A. E. (1857 [1858]). Vorläufige Zusammenstellung der Vögel Spaniens mit kritischer Benutzung der bisher von spanischen Ornithologen herausgegebenen Verzeichnisse. Allgemeine Deutsche Naturhistorische Zeitung. Im Auftrage der Gesellschaft ISIS in Dresden, N.F. 3: 431-448, 449-489.

Burham, K.K., Burham, W.A., Newton, I. (2009). Gyrfalcon Falco rusticolus post-glacial colonization and extreme long-term use of nest-sites in Greenland. Ibis 151, 514-522.

Bustamante, J., Molina, B., Del Moral, J. C. (Eds.). (2020). El cernícalo primilla en España, población reproductora en 2016-18 y método de censo. SEO/BirdLife. Madrid.

Bux, M., Giglio, G., Gustin, M. (2008). Nest box provision for lesser kestrel Falco naumanni populations in the Apulia region of southern Italy. Conservation Evidence 5, 58-61.

Cecere, J.G., De Pascalis, F., Imperio, S. et al. (2006). Urban effects on native avifauna: a review. Landscape and Urban Planning 74, 46-69.

Collins, R. Visigothic Spain, 404-711. (2004). Blackwell Publishing, Malden, MA, USA. 
Columella, Lucius Junius Moderatus (1471). Libri De Re Rustica. Florence, Filippo Giunta [in Latin].

Cook, S. E. (1834). Sketches in Spain during the years 1829, 30, 32 and 32. Paris, A. and. W. Galignani, Baudry, at the American Library.

Del Hoyo, J.; Elliot, A.; Sargatal, J., eds. (1992). "Threskiornithidae (Ibises and Spoonbills)".Handbook of the Birds of the World. Volume 1: Ostrich to Ducks. Barcelona:Lynx Edicions. p.472.

Erz, W. (1966). Ecological principles in the urbanization of birds. Ostrich: Journal of African Ornithology, 37, 357-363.

Ferguson-Lees, J., Christie, D.A. (2001). Raptors of the World. Houghton Mifflin Company, New York.

Ferreira, Diogo Fernandes (1616). Arte de Caça da Altaneria composta por Dioguo Fernandez Ferreira, moço da Camera del Rey, \& do seu serviço. Dirigida a Dom Francisco de Mello, Maerquez de Ferreyra, Conde de Tentugal \&c. Repartida em seis partes. na primeira trata da criaçao dos Gaviaes \& sua caça. Na segunda dos Assores \& sua caça. Na terceira dos Falcoes \& sua caça. Na quarta de suas doenças \& mezinhas. na quinta trata das Armadilhas. Na sexta da passagem \& peregrinaçao das aves. Com licença da S. Inquisiçao, Ordinario, \& Paço. Em Lisboa. $\mathrm{Na}$ officina de lorge Rodriguez.

Finlayson C, Brown K, Blasco R, Rosell J, Negro JJ et al. (2012). Birds of a Feather: Neanderthal Exploitation of Raptors and Corvids. PLOS ONE 7(9): e45927.

Franco, A., Andrada, J. (1976). Alimentación y selección de presa en Falco naumanni. Ardeola 23, 137-187.

Fuchs, S., Johnson, J.A., Mindell, D.P. (2015). Rapid diversification of falcons (Aves: Falconidae) due to expansion of open habitats in the Late Miocene. Molecular Phylogenetics and Evolution 82, 166-182.

Gahbauer, M.A., Bird, D.M., Clark, K.E., French, T., Brauning, D.W., McMorris, F.A. (2015). Productivity, Mortality, and Management of Urban Peregrine Falcons in Northeastern North America. The Journal of Wildlife Management 79(1):10-19.

García Petit, L. (2017). La explotación de las aves en época romana en la península Ibérica. Archaeofauna 26 53-65.

Garzón J. (1977). Birds of Prey in Spain, the Present Situation. In: World Conference on Birds of Prey, held in Vienna, 1-3 October, 1975: Report of Proceedings. Ed. R.D.Chancellor.

Germanodiu, S. (2015). Dovecotes from the Roman and Byzantine periods. An overview. HEROM. Journal of Hellenistic and Roman Material Culture. 4.1, 33-51.

González, J.L., Merino, M. (Eds.) (1990). El Cernícalo Primilla en la península Ibérica. Situación, problemática y aspectos biológicos. Serie Técnica. ICONA. Madrid. 
Hindmarch, S., Elliott, J.E., Mccann, S., Levesque, P. (2017). Habitat use by barn owls across a rural to urban gradient and an assessment of stressors including, habitat loss, rodenticide exposure and road mortality. Landscape and Urban Planning 164, 132-143.

Huerta, Gerónimo de (1624-1629). Historia natural de los animales de Cayo Plinio Segundo. Traducida por el Licenciado Geronimo de Huerta y ampliada por el mismo, con escolios y anotaciones, en que aclara lo escuro, y dudoso, y añade lo no salido hasta estos tiempos. Madrid, Luis Sanchez.

Cecere, J.G., De Pascalis, F., Imperio, S., Ménard, D., Catoni, C., Griggio, M. (2020). Inter-individual differences in foraging tactics of a colonial raptor: consistency, weather effects, and fitness correlates. Movement Ecology 8, 28.

Irby, L.H.L. (1875). The ornithology of the straits of Gibraltar. $2^{\text {nd }}$ ed. London: R. H. Porter.

Jovani R, Serrano D, Ursúa E, Tella JL (2008). Truncated Power Laws Reveal a Link between Low-Level Behavioral Processes and Grouping Patterns in a Colonial Bird. PLOS ONE 3(4): e1992. Doi:10.1371/journal.pone.0001992.

Kennedy, H. (1996). Muslim Spain and Portugal. A Political History of al-Andalus. Taylor and Francis Group, London and NY.

Keymer, J.E., Marquet, P.A., Jorge X. Velasco-Hernández, J.X., Levin, S. Extinction Thresholds and Metapopulation Persistence in Dynamic Landscapes. Am. Nat. 156, pp. 478-494 (2000).

Kumar, K. (2019). Visions of Empire: How Five Imperial Regimes Shaped the World. Princeton University Press.

Larson, D., Matthes U., Kelly, P.E., Lundholm, J., Gerrath, J. (2004). The Urban Cliff Revolution. Origins and Evolution of Human Habitats. Fitzhenry \& Whiteside, Markham, Ontario.

Levins, R. (1970). Extinction. Some Mathematical Questions in Biology (ed. M. Gerstenhaber), pp. 77-107. American Mathematical Society, Providence, R. I.

Li, Z., Zhou, Z., Deng, T., Li, Q., Clarke, J.A. (2014). A falconid from the Late Miocene of northwestern China yields further evidence of transition in Late Neogene steppe communities. The Auk 131, 335-350.

Lilford, L. (1865). Notes on the Ornithology of Spain. The Ibis, vol. II (New series): 166-177.

Machado, A. (1854). Catálogo de las aves, observadas en algunas provincias de Andalucía. Sevilla, Imprenta y taller de encuadernaciones de Juan Moyano.

Manetti, X., Lorenzo, L. \& Violante, V. (1767-1776). Ornithologia methodice digesta atque iconibus aeneis ad vivum illuminatis ornata. 5 vols. Florence, in aedibus Mouckianis, apud C. Cambiasium Typographum Regium, Typographia losephi Vanni [in Latin]. 
Martínez de Espinar, Alonso (1644). Arte de Ballesteria, y Monteria, escrita con metodo, para escusar la fatiga, que ocasiona la ignorancia: Dividida en Tres Libros. En el primero se declaran las definiciones de la Ballesteria, Monteria, Chucheria, y Cetreria, Se trata de los Elementos, y de todos los instrumentos necessarios para el uso deste Arte. En el segundo, se dizen las naturalezas de los Animales... En el tercero, se declaran las calidades de las Aves, y el modo de caçarlas... Dedicale al Serenissimo Señor Don Baltasar Carlos Filipe de Austria... Alonso Martinez de Espinar, que dà el Arcabuz a su Magestad, y Ayuda de Camara del Principe Nuestro Señor. En Madrid, En la Imprenta Real.

McDonnell, M.J. and Hahs, A.K. (2015). Adaptation and Adaptedness of Organisms to Urban Environments. Annu. Rev. Ecol. Evol. Syst. 46, 261-80.

McEvedy,C., Richard, J. (1978). Atlas of world population history. New York: Penguin Books.

Møller, A.P., Xia, C. (2020). The ecological significance of birds feeding from the hand of humans.Sci Rep 10,9773. https://doi.org/10.1038/s41598-020-66165-9.

Moulton, M.P., Wendell P. Cropper Jr., W.P., Avery, M.L., Moulton, L.E. (2010). The earliest House Sparrow introductions to North America. Biol Invasions 12, 2955-2958.

Mueller JC, Carrete M, Boerno S, et al. (2020). Genes acting in synapses and neuron projections are early targets of selection during urban colonization. Mol Ecol mec.15451. doi: 10.1111/mec.15451.

Mueller JC, Kuhl H, Boerno S, et al. (2018). Evolution of genomic variation in the burrowing owl in response to recent colonization of urban areas. Proc $R$ Soc B Biol Sci 285:20180206. doi: 10.1098/rspb.2018.0206.

Negro JJ, de la Riva, M, Bustamante, J. (1991). Patterns of winter distribution and abundance of lesser kestrels (Falco naumanni) in Spain. Journal of Raptor Research 25, 30-35.

Negro, J.J. (1997). Lesser Kestrel Falco naumanni. BWP Update 1, 49-56.

Negro, J.J., Hiraldo, F. (1993). Nest-site selection and breeding success in the lesser kestrel Falco naumanni. Bird Study, 40, 115-119.

Negro, J.J. (1991). Ecología de poblaciones del cernícalo primilla, Falco naumanni. PhD Thesis. University of Sevilla.

Nicholson, E. M. (1929). Report on the "British Birds" Census of Heronries, 1928. Brit. Birds, 22: 269-323, 333-72.

O'Callaghan, J. F. (2013). A History of Medieval Spain. Cornell University Press.

Parr, S.J., Sklyarenko, S., Brokhovich, S., Brookhouse, J., Collin, P.N., Heredia, B. (2000). A baseline survey of lesser kestrel Falco naumanni in south-east Kazakhstan. Sandgrouse 22(1), $1-9$. 
Peresani, M., Fiore, I., Gala, M., Romandini, M., Tagliacozzo, A. (2011). Late Neandertals and the intentional removal of feathers as evidenced from bird bone taphonomy at Fumane Cave 44 ky B.P., Italy. Proceedings of the National Academy of Sciences, 108 (10) 3888-3893.

Plinius, Caius (Secundus) (1469). Libros Naturalis Historiae. Venice, J. Spira [in Latin].

Pollock, C.J., Capilla-Lasheras, P., McGill, R.A.R.et al. (2017). Integrated behavioural and stable isotope data reveal altered diet linked to low breeding success in urban-dwelling blue tits (Cyanistes caeruleus). Sci Rep 7, 5014. https://doi.org/10.1038/s41598-017-04575-y

Richmond. I.A. (1931). Five Town-Walls in Hispania Citerior. The Journal of Roman Studies, Vol. $21,86-100$.

Riddell, W.H. (1945). Field notes from observations in Spain on birds in the British list. Ibis 87, 407-422.

Ring, T., Watson, N., Schellinger, P. (2013). The Americas: International Dictionary of Historic Places. Routledge. pp.560.

Rodríguez, A., Alcaide, M., Negro, J.J., Pilard, P. (2011). Using major histocompatibility complex markers to assign the geographic origin of migratory birds: Examples from the threatened lesser kestrel. Anim Conserv 14, 306-313.

Rodríguez, A., Negro, J.J., Bustamante, J., et al (2009). Geolocators map the wintering grounds of threatened Lesser Kestrels in Africa. Divers Distrib 15, 1010-1016.

Rodríguez, A., Negro, J.J., Bustamante, J., Antolín, J. (2013). Establishing a Lesser Kestrel Colony in an Urban Environment for Research Purposes. J Raptor Res 47:214-218.

Rodríguez, C., Bustamante, J. (2008). Patterns of Orthoptera abundance and lesser kestrel conservation in arable landscapes. Biodiversity and Conservation 17(7),1753-1764.

Sánchez-Marco, A. (2004). Avian zoogeographical patterns during the quaternary in the Mediterranean region and paleoclimatic interpretation. Ardeola 51(1), 91-132.

Sanz, C., Romero, F., Górriz, C., De Pablo, R. (2011). El foso y el sistema defensivo de Pintia (Padilla de Duero/Peñafiel, Valladolid). Revista d'Arqueologia de Ponent 21, 221-232.

Sanz, C., Romero, F., Olteanu, T., Górriz, C., De Pablo, R. (2010). Los sistemas defensivos de Pintia. En: Sanz, C. y Romero, F. (Eds.). Vaccea Anuario 2009. Universidad de Valladolid Centro de Estudios Vacceos "Federico Wattenberg". Valladolid: 13-19.

Sarà, M, Bondì, S, Bermejo, A, et al. (2019). Broad-front migration leads to strong migratory connectivity in the lesser kestrel (Falco naumanni). J Biogeogr. 46, 2663- 2677.

Saunders, H. (1871). A List of the Birds of Southern Spain. Ibis, I (Third Series): 54-68; 205-225; 384-402.

Schorger, A. (1952). Introduction of the domestic pigeon. Auk 69, 462-463.

Serrano, D., Tella, J.L. (2003). Dispersal within a spatially structured population of lesser kestrels: the role of spatial isolation and conspecific attraction. J. Anim. Ecol. 72, 400-410. 
Shady Solis, R, Haas, J, Creamer, W. (2001). Dating Caral, a Preceramic Site in the Supe Valley on the Central Coast of Peru. Science 292 (5517), 723-726.

Summers-Smith, D. (1988). The Sparrows: a study of the genus Passer. T. \& A.D. Poyser. Staffordshire, U.K.

Tella, J.L., Hiraldo, F., Donázar, J.A., Negro, J.J. (1996). Costs and benefits of urban nesting in the Lesser Kestrel, in: Bird, D., Varland, D. and Negro, J.J., (Eds.), Raptors in Human Landscapes: Adaptions to Built and Cultivated Environments. Academic Press, London, 53-60.

Thacher Cooke, M. (1928). The spread of the European Starling in North America (to 1928). United States Department of Agriculture, Circular No. 40.

Tyrberg, T. (1998). Pleistocene birds of the Palearctic: a catalogue. Publications of the Nuttall Ornithological Club No. 27, Cambridge, Mass.

Tyrberg, T. (2008). Online Supplement to Pleistocene birds of the Palearctic: a catalogue (Publications of the Nuttall Ornithological Club No. 27, Cambridge, Mass. Last updated February 24, 2008.

Vidal Teruel, N.O., Campos Carrasco, J.M., Gómez Rodríguez, A. (2010). La ocupación del entorno rural de Onoba en época romana: la villa de "La Almagra" (Huelva). Huelva en su Historia - 2a época, 13, 31-50.

Vidal-Mateo, J., Romero, M., Urios, V. (2019). How can the home range of the Lesser Kestrel be affected by a large civil infrastructure? Avian Res 10, 10.

Watson, H., Videvall, E., Andersson, M.et al. (2017). Transcriptome analysis of a wild bird reveals physiological responses to the urban environment. Sci Rep 7, 44180.

https://doi.org/10.1038/srep44180.

Wink, M., Sauer-Gürth, H. \& Pepler, D. (2004). Phylogeographic relationships of the Lesser Kestrel (Falco naumanni) in breeding and wintering quarters inferred from nucleotide sequences of the mitochondrial cytochrome b gene. In Raptors worldwide. Chancelor, R.D. \& Meyburg, B.-U. (Eds). Berlin: WWGBP.

\section{ACKNOWLEDGEMENTS}

The lesser kestrel database for Andalusia from 2003-2018 was obtained from "Red de Información Ambiental de Andalucía (REDIAM): Programa de Emergencias, Control Epidemiológico y Seguimiento de Fauna Silvestre de Andalucía. Seguimiento de Aves Terrestres Amenazadas de Andalucía, Consejería de Agricultura, Ganadería, Pesca y Desarrollo Sostenible. Junta de Andalucía".

\section{AUTHOR CONTRIBUTIONS}


$J J N$. conceived and designed the study with input from all other authors. JJN, JP, and AR processed the data. ARF obtained and translated classical references from latin. AR and JP produced the figures. JJN. wrote the manuscript with input from all authors. All authors reviewed the manuscript and gave their final approval for publication.

\section{ADDITIONAL INFORMATION}

Competing Interests: The authors declare no competing interests 
FIGURE LEGENDS 